\title{
Copper and Lead Ions Removal by Electrocoagulation: Process Performance and Implications for Energy Consumption
}

\author{
Aji Prasetyaningrum*, Dessy Ariyanti, Widayat Widayat, Bakti Jos
}

Department of Chemical Engineering, Faculty of Engineering, Diponegoro University, Jl. Prof. Soedarto S.H., Tembalang, Semarang 50275, Indonesia.

\begin{abstract}
Electroplating wastewater contains high amount of heavy metals that can cause serious problems to humans and the environment. Therefore, it is necessary to remove heavy metals from electroplating wastewater. The aim of this research was to examine the electrocoagulation (EC) process for removing the copper $(\mathrm{Cu})$ and lead $(\mathrm{Pb})$ ions from wastewater using aluminum electrodes. It also analyzes the removal efficiency and energy requirement rate of the EC method for heavy metals removal from wastewater. Regarding this matter, the operational parameters of the EC process were varied, including time (20-40 min), current density $\left(40-80 \mathrm{~A} / \mathrm{m}^{2}\right), \mathrm{pH}$ (3-11), and initial concentration of heavy metals. The concentration of heavy metals ions was analyzed using the atomic absorption spectroscopy (AAS) method. The results showed that the concentration of lead and copper ions decreased with the increase in EC time. The current density was observed as a notable parameter. High current density has an effect on increasing energy consumption. On the other hand, the performance of the electrocoagulation process decreased at low $\mathrm{pH}$. The higher initial concentration of heavy metals resulted in higher removal efficiency than the lower concentration. The removal efficiency of copper and lead ions was $89.88 \%$ and $98.76 \%$, respectively, at 40 min with electrocoagulation treatment of $80 \mathrm{~A} / \mathrm{m}^{2}$ current density and $\mathrm{pH} 9$. At this condition, the specific amounts of dissolved electrodes were $0.2201 \mathrm{~kg} / \mathrm{m}^{3}$, and the energy consumption was $21.6 \mathrm{kWh} / \mathrm{m}^{3}$. The kinetic study showed that the removal of the ions follows the first-order model.
\end{abstract}

Keywords: Heavy metals; electrocoagulation; energy consumption; kinetics; copper; lead

Article History: Received: $16^{\text {th }}$ July 2020; Revised: $15^{\text {th }}$ Dec 2020; Accepted: $20^{\text {th }}$ January 2021; Available online: $17^{\text {th }}$ February 2021 How to Cite This Article: Prasetyaningrum, A., Ariyanti, D., Widayat, W., Jos, B. (2021) Copper and Lead Ions Removal by Electrocoagulation: Process Performance and Implications for Energy Consumption. Int. Journal of Renewable Energy Development, 10(3), 415-424. https://doi.org/10.14710/ijred.2021.31665

\section{Introduction}

The metal coating industry disposes of large amounts of liquid wastewater that contains a variety of hazardous and toxic heavy metals, namely alkaline cleaning agents, oil, fat, copper, chromium, nickel, cyanide, zinc, and degreasing solvents (Akbal and Camcı 2011; Hunsom et al. 2005; Prasetyaningrum et al. 2019). If they are released into the environment with no treatments, most of those metals can harm the environment. Common methods such as chemical, physical, and biological processes can be utilized to treat heavy metals present in wastewater. Those methods include the utilization of $\mathrm{NaOH}$ in the precipitation process and $\mathrm{Al}_{2}\left(\mathrm{SO}_{4}\right)_{3}$ or $\mathrm{FeSO}_{4}$ in the coagulation process with subsequent time-consuming sedimentation, ion exchange, biosorption, precipitation, adsorption, reverse osmosis, filtration, and membrane collection (Reverberi et al. 2014; Adhoum et al. 2004; Tchobanoglous et al. 2003).

The precipitation method is a simple and common process to remove the heavy metals in wastewater. Basically, this method is conducted using chemical coagulants, mostly aluminum or iron salts, to convert the pollutants into colloidal material and regulate the $\mathrm{pH}$ of wastewater (Agridiotis et al. 2007). However, that method produces byproducts as secondary pollutants that may harm the environment (Shahedi et al. 2020).

One of the promising process to treat heavy metal content in the wastewater is electrocoagulation (EC). Compared to the other methods, there are several points of interest of the EC process, such as: having high-quality effluents, low energy consumption, low dissolved solids, and low sludge formation (Moradi et al. 2021; Samsami et al. 2020; Chen 2004; Zhu et al. 2005). In addition, it is very environmentally compatible, versatile, cost-effective (Cotillas et al. 2014), and provides opportunities to apply inherent safety principles (Fabiano et al. 2014) without executing strict safety standards (Abrahamsen et al. 2013).

During the EC process, no chemicals were included to form coagulant. Besides, it was governed by the electric field, generally direct current (DC) charges, to the wastewater solutions through sacrificial electrodes made of iron or aluminum (Akbal and Camcı 2011; Shahedi et al. 2020; Chen 2004). The air is oxidized to produce oxygen gas and hydrogen ions $\left(\mathrm{H}^{+}\right)$due to the difference in

\footnotetext{
* Corresponding author: aji.prasetyaningrum@che.undip.ac.id
} 
electrical potential of the cathodic and anodic electrodes. Furthermore, the oxidized metal produces additional cations, with an occurrence of air reduction at the cathode to produce hydroxyl ions $\left(\mathrm{OH}^{-}\right)$and hydrogen gas simultaneously. Aluminum (Al) was chosen as the electrode for this study because it shows higher performance than the iron (Fe) electrode (Chen et al. 2018; Prasetyaningrum et al. 2018). The redox reaction in an aluminum electrode system under basic conditions can be summarized in the reaction equations below (Eq. (1)-(9)) (Pulkka et al. 2014).

$$
\begin{aligned}
& \text { Anode } \quad: \mathrm{Al}_{(\mathrm{s})} \rightarrow \mathrm{Al}^{3+}{ }_{(\mathrm{aq})}+3 \mathrm{e}^{-} \\
& \text {Cathode } \quad: 3 \mathrm{H}_{2} \mathrm{O}_{(\mathrm{l})}+3 \mathrm{e}^{-} \rightarrow 1.5 \mathrm{H}_{2(\mathrm{~g})}+3 \mathrm{OH}^{-} \\
& \text {Precipitation : } \mathrm{Al}^{3+}{ }_{(\mathrm{aq})}+3 \mathrm{OH}^{-}{ }_{(\mathrm{aq})} \rightarrow \mathrm{Al}(\mathrm{OH})_{3(\mathrm{~s}) \downarrow}
\end{aligned}
$$

Under low $\mathrm{pH}$ conditions, the reactions as follows:

Anode $\quad: \mathrm{Al}_{(\mathrm{s})} \rightarrow \mathrm{Al}^{3+}{ }_{(\mathrm{aq})}+3 \mathrm{e}^{-}$

Precipitation: $\mathrm{Al}^{3+}{ }_{(\mathrm{aq})}+3 \mathrm{H}_{2} \mathrm{O}_{(\mathrm{l})} \rightarrow \mathrm{Al}(\mathrm{OH})_{3(\mathrm{~s}) \downarrow}+3 \mathrm{H}^{+}{ }_{(\mathrm{aq})}$

Cathode $\quad: 3 \mathrm{H}^{+}{ }_{(\mathrm{aq})}+3 \mathrm{e}^{-} \rightarrow 1.5 \mathrm{H}_{2(\mathrm{~g})}$

Overall $\quad: \mathrm{Al}_{(\mathrm{s})}+3 \mathrm{H}_{2} \mathrm{O}_{(\mathrm{l})} \rightarrow \mathrm{Al}(\mathrm{OH})_{3(\mathrm{~s}) \downarrow}+1.5 \mathrm{H}_{2(\mathrm{~g})}$

EC process was widely applied for treatment process of various types of wastewater (Moradi et al. 2020; AlShannag et al. 2013), pulp and paper mill industries (AlShannag et al. 2013; Pandey and Thakur 2020), olive mills (Flores et al. 2018), textile processing (Bener et al. 2019), manufacture of potato chips (Kobya et al. 2006), baker's yeast production (Kobya and Delipinar 2008), and pigments industries (Martınez-Huitle and Brillas 2009). Numerous studies have proven that the EC process has high effectivity in the removal of heavy metal ions from industrial/synthesized wastewater (Zini et al. 2020; Akbal and Camc1 2011; Adhoum et al. 2004; Basha et al. 2008).

There are several reports on the EC process utilization in pollutants removal from wastewater; however, the research which studies the influence of process parameters on the EC process performance and energy requirements is still limited. The objective of this study is to analyze parameters that affect EC process performance and energy consumption in $\mathrm{Cu}$ and $\mathrm{Pb}$ ions removal from synthesized wastewater by utilizing the EC process. The kinetic models of $\mathrm{Cu}$ and $\mathrm{Pb}$ removal in the time of the $\mathrm{EC}$ process are also interesting to be explored. Furthermore, the data obtained from the reaction kinetics model and energy consumptions are useful for designing large-scale EC processes.

\section{Materials and Methods}

\subsection{Experimental setup}

The process has been carried out using synthesized wastewater containing an initial Lead $(\mathrm{Pb})$ and Copper $(\mathrm{Cu})$ concentration of $10.92 \mathrm{ppm} 147.6 \mathrm{ppm}$, respectively. The initial wastewater concentration samples were referred to the composition of $\mathrm{Pb}$ and $\mathrm{Cu}$ from an industrial electro-plant located at Juwana, Pati, Central Java, Indonesia. Wastewater samples utilized in this study were prepared using $\mathrm{Pb}\left(\mathrm{NO}_{3}\right)_{2}(\geq 99.5 \%$, Merck Cat No. 107398) and $\mathrm{CuSO}_{4}$ (99\%>, Merck Cat No. 102790).
The initial wastewater concentration samples were referred to the composition of $\mathrm{Cu}$ and $\mathrm{Pb}$ from the wastewater of industrial electroplating located at Juwana, Pati, Central Java, Indonesia.

The EC reactor for the experiments was filled with 600 $\mathrm{mL}$ of the wastewater solution. Aluminum electrodes were utilized as the cathodes and anodes with width, length, and thickness were $5 \mathrm{~cm}, 10 \mathrm{~cm}$, and $1 \mathrm{~mm}$, respectively. A power supply with direct-current (DC) and voltage ranging at $0-30 \mathrm{~V}$, current density ranging at $0-8 \mathrm{~A}$ and controlled by a potentiostat were connected to the aluminum electrodes, at an ambient temperature of $27 \pm 1$ ${ }^{\circ} \mathrm{C}$. The samples $(5-7 \mathrm{~mL})$ were analyzed periodically. The filtrate was taken to measure the concentration of lead and copper ions. After the experiment, the EC reactor was rinsed using $\mathrm{HCl}$ solution and washed using distilled water. Therefore, the heavy metal ions, as well as the original and treated wastewater, were filtered before analyzing the concentrations. Atomic Absorption Spectrophotometer (AA-7000 Shimadzu) was used to measure the concentration of $\mathrm{Cu}$ and $\mathrm{Pb}$ ions in the filtrate. Moreover, the adjustment of the $\mathrm{pH}$ value of wastewater to the desired value was conducted using 0.1 $\mathrm{M} \mathrm{NaOH}$ (E. Merck Cat. No. 104698) or $0.1 \mathrm{M} \mathrm{H}_{2} \mathrm{SO}_{4}$ (E. Merck Cat. No. 100317). The $\mathrm{pH}$ was measured using portable $\mathrm{pH}$ meters (HI 8424 Hanna). The experiment was conducted in triplicate to minimize experimental errors.

\subsection{Characterization}

Following the EC process, the sample was strained in order to separate the deposits/precipitates. The concentration of $\mathrm{Cu}$ and $\mathrm{Pb}$ ions were tested by Atomic Absorption Spectrophotometer (AA-7000, Shimadzu). Orion Star (A3225) conductivity meter was used to analyze the wastewater electrical conductivity (o).

The percent (\%) removal efficiency of copper and lead ions removal were calculated using Eq. (10) as follows:

$$
\eta(\%)=\frac{C_{0}-C_{t}}{C_{0}} \times 100
$$

where $C_{0}$ represents the concentration at initial condition, and $C_{t}$ is the treated concentration of $\mathrm{Pb}$ and $\mathrm{Cu}$ ions during the EC process, respectively.

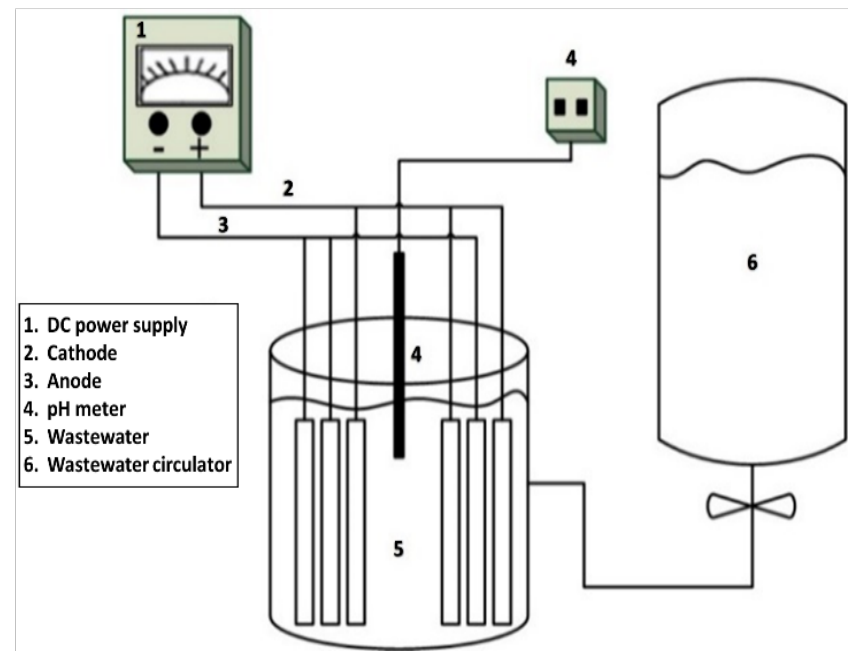

Fig. 1 The experimental setup of electrocoagulation process 
The energy requirements per unit volume were calculated using Eq. (11) as follows:

$$
E=\frac{P \times I \times t}{V}
$$

where $E$ represents the specific energy requirement $\left(\mathrm{kWh} / \mathrm{m}^{3}\right), t$ is the time of EC process (h), $P$ represents the applied voltage (Volt), $I$ denotes the direct current (A), and $V$ denotes the volume of the treated wastewater $\left(\mathrm{m}^{3}\right)$. The expenditure on the electrical energy requirements and the mass loss of electrodes greatly influence the total cost of wastewater treatment with the EC process.

The mass losses of the aluminum electrodes $m_{A l}$ can be calculated using Eq. (12), which follows Faraday's law.

$$
m_{A l}=\frac{I \times t \times M w_{A l}}{z_{A l} \times F \times V}
$$

Where $m_{A l}$ denotes the dissolved electrode $\left(\mathrm{kg} / \mathrm{m}^{3}\right), I$ denotes the direct electrical current (A), $t$ represents the time of the EC process (s), MwAl denotes the $\mathrm{Al}$ molecular weight $(27 \mathrm{~g} / \mathrm{mol}), z_{A l}$ denotes the $\mathrm{Al}$ chemical equivalence $\left(z_{A l}=3\right), F$ denotes the Faraday constant $(\mathrm{F}=96500$ $\mathrm{C} / \mathrm{mol}$ ), and $V$ denotes the treated wastewater volume $\left(\mathrm{m}^{3}\right)$.

\subsection{Kinetics model}

Two models, namely the first-order and pseudo-first-order models, were evaluated to describe the kinetic rate of $\mathrm{Cu}$ and $\mathrm{Pb}$ ions removal from wastewater. The degradation of $\mathrm{Cu}$ and $\mathrm{Pb}$ ions concentration is shown in the equation below (Eq. (13)).

$$
-\frac{d C_{t}}{d t}=-r
$$

Where $C_{t}(\mathrm{mg} / \mathrm{L})$ denotes the $\mathrm{Cu}$ and $\mathrm{Pb}$ ions concentration at EC time $t$ (min) and (-r) is the removal rate of $\mathrm{Cu}$ and $\mathrm{Pb}$ ions. In the first-order model equation, the value of $(-r)$ is described as $\left(-r=k_{1} . C_{t}\right)$, where $k_{1}$ is the kinetic rate constant of the first-order model. The integration of Eq. (13) at the boundary condition of $\mathrm{C}_{t}=\mathrm{C}_{0}$ at $\mathrm{t}=0$ and $\mathrm{C}_{t}=\mathrm{C}_{\mathrm{t}}$ at $\mathrm{t}=\mathrm{t}$ gives:

$$
C_{t}=C_{0} e^{-k_{1} t}
$$

The linearization of (Eq. (14)) gives:

$$
\ln C_{t}=-k_{1} t+\ln C_{0}
$$

By plotting Eq. (15), the value of $k_{1}$ can be obtained from the value of the slope.

For the pseudo-first-order model, the value of $(-r)$ is described as $\left(k_{a p p}\left(C_{t}-C_{e}\right)\right)$. Therefore, Eq. (13) can be rewritten as follows:

$$
-\frac{d C_{t}}{d t}=k_{a p p}\left(C_{t}-C_{e}\right)
$$

where $C_{e}$ is the $\mathrm{Cu}$ and $\mathrm{Pb}$ ions concentration at equilibrium condition. The integration of Eq. (16) with the boundary conditions of $\mathrm{C}_{\mathrm{t}}=\mathrm{C}_{0}$ at $\mathrm{t}=0$ and $\mathrm{C}_{\mathrm{t}}=\mathrm{C}_{\mathrm{t}}$ at $\mathrm{t}=\mathrm{t}$ is obtained as follows:

$$
C(t)=C_{e}+\left(C_{0}-C_{e}\right) e^{-k_{a p p} t}
$$

where $C_{e}$ denotes the $\mathrm{Cu}$ and $\mathrm{Pb}$ ions concentration at equilibrium, $C_{0}$ denotes the concentration at initial condition, and $k_{\text {app }}$ represents the kinetic rate constant of the pseudo-first-order model.

\section{Results and Discussions}

\subsection{The Effects of Parameters}

\subsubsection{The Effect of Current Density}

Several researchers reported that one of the important parameters affecting the heavy metal ions removal using the EC process is current density (Das and Nandi 2019; Prasetyaningrum et al. 2019; Chen et al. 2018). Therefore, in this study, the current density was varied, including 40 , $50,60,70$, and $80 \mathrm{~A} / \mathrm{m}^{2}$, in order to investigate its effect on $\mathrm{Cu}$ and $\mathrm{Pb}$ ions removal. Fig. 2 shows the degradation profile of copper and lead ions during the EC process for $40 \mathrm{~min}$ at $\mathrm{pH}=9$ and $\sigma=9.0 \mathrm{mS} / \mathrm{cm}$.
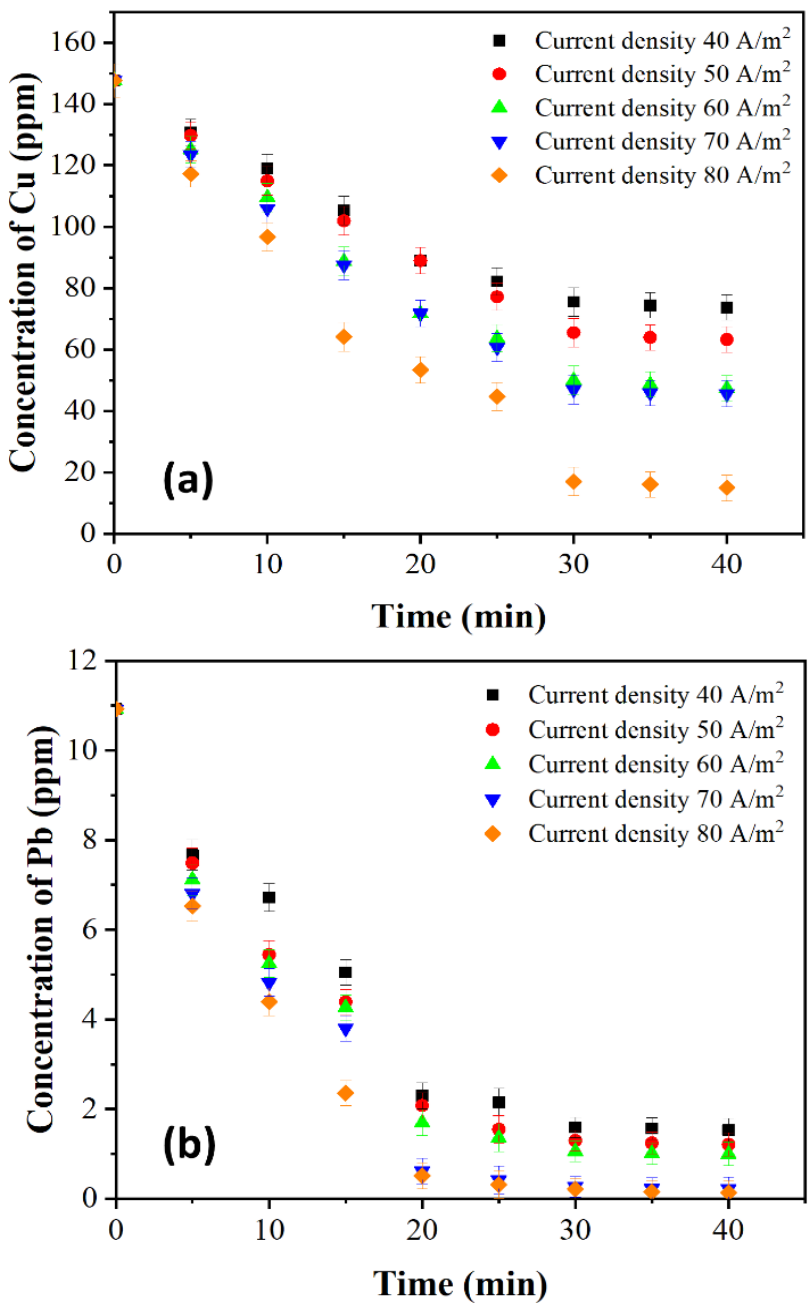

Fig. 2 Degradation profile of : (a) copper ions (b) lead ions during the EC process at a different current density 


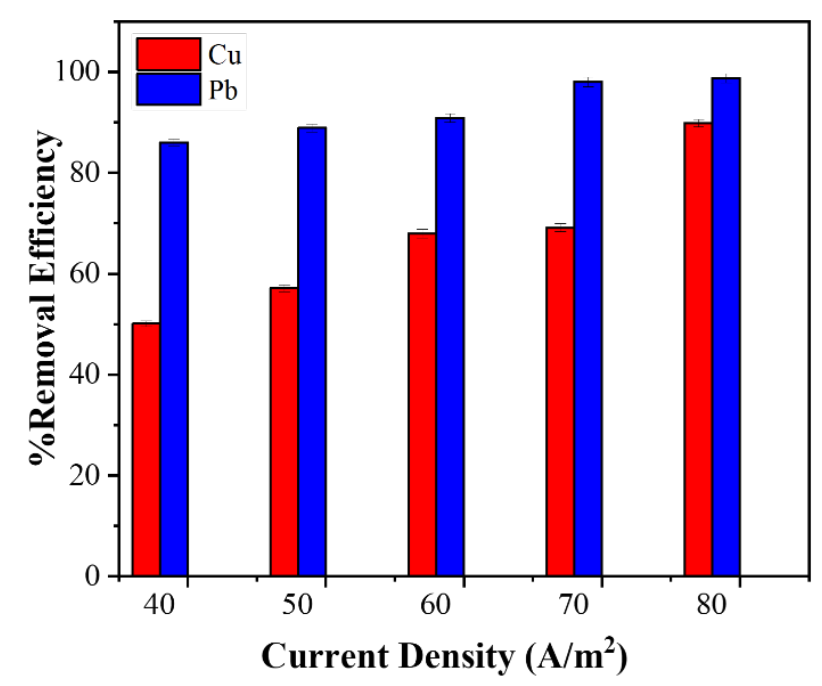

Fig. 3 The removal efficiencies of copper and lead ions at varied direct current density.

The concentration of copper ion decreases from 147.63 ppm to $73.69,63.27,47.32,45.57$, and $14.94 \mathrm{ppm}$ at the current density of $40,50,60,70$, and $80 \mathrm{~A} / \mathrm{m}^{2}$, respectively. On the other hand, the lead ion concentration decreases from $10.92 \mathrm{ppm}$ to $2.29,2.07,1.69,0.61$, and $0.50 \mathrm{ppm}$ at current density of $40,50,60,70$, and $80 \mathrm{~A} / \mathrm{m}^{2}$, respectively.

Fig. 3 shows the influence of varied current densities values on the efficiencies of $\mathrm{Cu}$ ad $\mathrm{Pb}$ removal. The $\mathrm{Cu}$ removal efficiencies are 50.08\%, 57.14\%, 67.95\%, 69.135, and $89.88 \%$ for current densities $40,50,60,70$ and $80 \mathrm{~A} / \mathrm{m}^{2}$ respectively. In addition, the removal efficiencies of lead are $86.01 \%, 88.92 \%, 90.91 \%, 98.01 \%$, and $98.76 \%$ for current densities $40,50,60,70$ and $80 \mathrm{~A} / \mathrm{m}^{2}$, respectively. It is found that above $70 \mathrm{~A} / \mathrm{m}^{2}$, the removal efficiency of heavy metals ions remains unchanged for further higher current densities. Thus, further studies were conducted at $80 \mathrm{~A} / \mathrm{m}^{2}$.

Since the value of current density increases, it is found that the $\mathrm{Cu}$ and $\mathrm{Pb}$ ions removal efficiencies increase. This improvement is because of the generation of coagulant $\left(\mathrm{Al}^{3+}\right.$ ions) in a higher amount at higher current density (Das and Nandi 2019). It means that the higher the value of current density, the higher the possibility of the anode dissolution. Therefore, high amounts of metal hydroxide flocs that can increase the efficiency in removing $\mathrm{Cu}$ and $\mathrm{Pb}$ ions from the solution are formed. Consequently, the removal efficiency of $\mathrm{Cu}$ and $\mathrm{Pb}$ ions from the solution increases. Besides, increasing the current density increases the number of charged electrons that can damage the stability of the molecular bonds in the pollutants (Prasetyaningrum et al. 2019). Therefore, the metal ions will easily form oxide complexes. This destabilization leads to the formation of oxide complexes, which further flocculated and precipitated.

This result is following some preceding studies. Chen et al. (2018) identified the current density as the essential factor that can affect the EC process performance. It further specifies the quantity of $\mathrm{Al}^{3+}$ and $\mathrm{OH}^{-}$that were formed during the EC process and also increases the current density required to remove heavy metal ions. Beyazit (2014) reported that $100 \%$ of $\mathrm{Cu}$ removal was obtained at a current density of $90 \mathrm{~A} / \mathrm{m}^{2}$. Hossain et al.
(2013) reported that, by increasing the current density about 50 to $125 \mathrm{~A} / \mathrm{m}^{2}$ could increase the removal efficiency. This improvement is caused by the ion formation in a high amount on the electrodes. These ions can promote pollutant molecules destabilization. Another research reported by Nasrullah et al. (2012) explained that increasing current density in sewage treatment could increase the high removal efficiency of COD, BOD, and suspended solids. Pertaining to the difference between the results in this study and other studies is due to differences in the concentration of the wastewater solution and the performance of the equipment used during the EC process.

\subsubsection{The Effect of $p H$}

Moussa et al. (2017) reported that $\mathrm{pH}$ value of the wastewater solution is one of the important parameters affecting the EC process performance. The concentration degradation profiles of $\mathrm{Cu}$ and $\mathrm{Pb}$ ions at different $\mathrm{pH}$ value, including 3, 5, 7, 9, and 11, are presented in Fig. 4. The current density was maintained at $80 \mathrm{~A} / \mathrm{m}^{2}$.
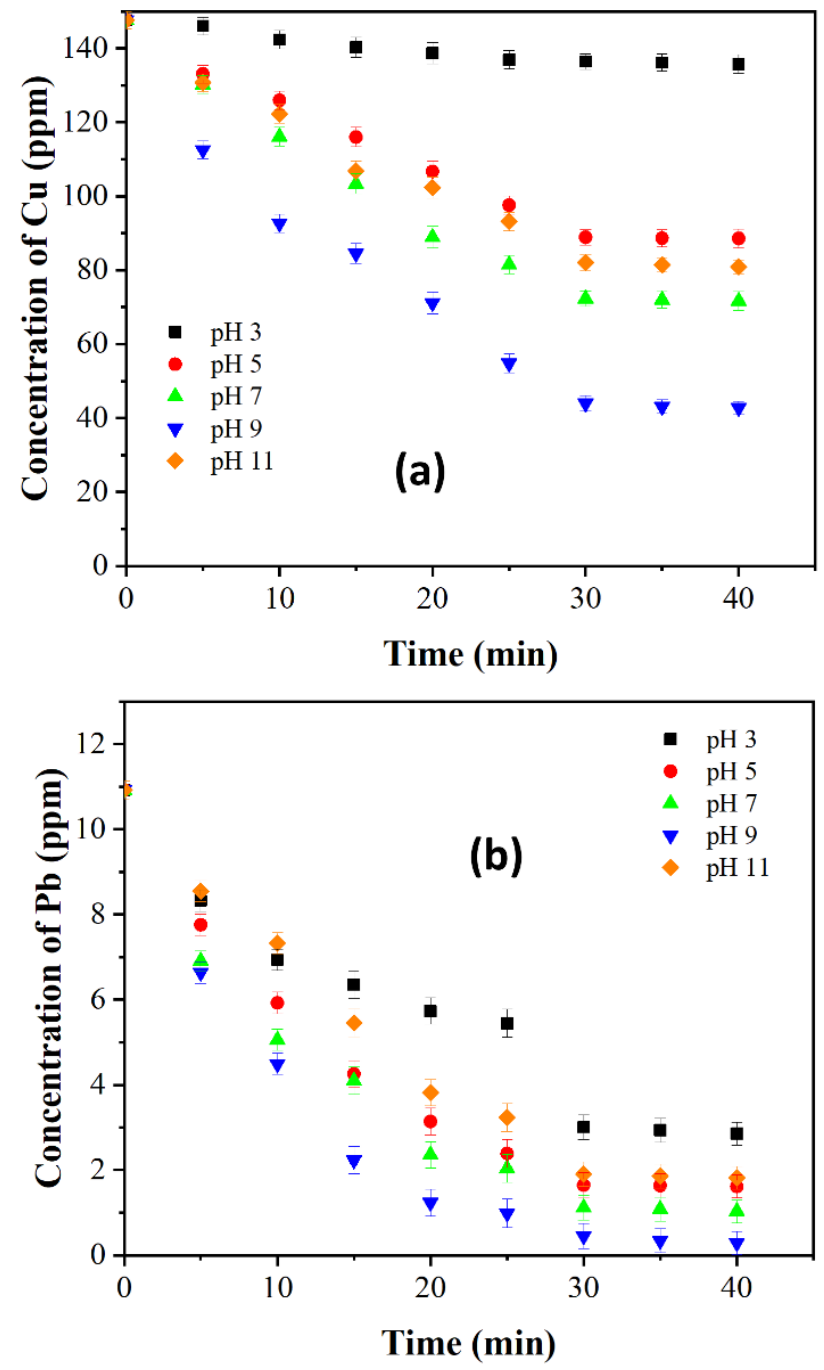

Fig. 4 Degradation profile of :(a) copper ions (b) lead ions during the EC process at different $\mathrm{pH}$ 


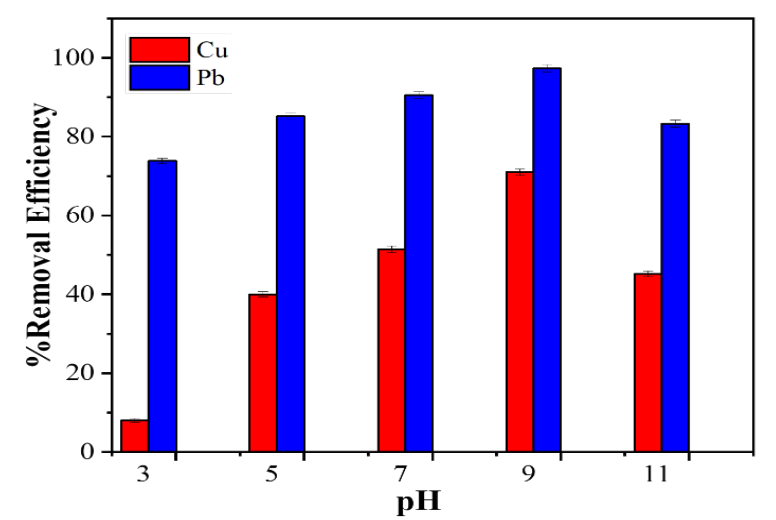

Fig. 5 Removal efficiencies of copper and lead ions at different $\mathrm{pH}$

Besides, the removal efficiency of $\mathrm{Cu}$ and $\mathrm{Pb}$ ions at different $\mathrm{pH}$ value is shown in Fig. 5. As can be observed from Fig. 5, the $\mathrm{pH}$ value of wastewater significantly influences the removal of $\mathrm{Cu}$ and $\mathrm{Pb}$ ions. The $\mathrm{Cu}$ ion removal efficiencies are 8.02\%, 40.01\%, 51.44\%, 71.03\% and $45.21 \%$ at $\mathrm{pH} 3,5,7,9$ and 11 , respectively. Surprisingly, the removal efficiencies of lead ions are $73.86 \%, 85.21 \%, 90.54 \%, 99.38 \%$ and $83.34 \%$ at $\mathrm{pH} 3,5,7$, 9 , and 11 , respectively.

As shown in Fig. 5, the $\mathrm{Cu}$ and $\mathrm{Pb}$ ions removal efficiency increases as the $\mathrm{pH}$ of wastewater increases. This improvement is caused by the increase in $\mathrm{OH}^{-}$species as the $\mathrm{pH}$ value increases. As the $\mathrm{OH}^{-}$species increases, the metal hydroxide formation as the coagulants or flocs increases. Therefore, the copper and lead ions removal increase as the $\mathrm{pH}$ value of wastewater increases from 3 to 9. Kim et al. (2020) stated that at acidic $\mathrm{pH}$, the metal hydroxide is difficult to be generated because the $\mathrm{OH}^{-}$ion is difficult to be formed. In contrast, the formation of metal hydroxides can be easily conducted in alkaline conditions. Hence, the efficiency of heavy metals removal increases.

However, as can be observed in Fig. 5, the efficiency of $\mathrm{Cu}$ and $\mathrm{Pb}$ ions removal decreases at the further alkaline condition. At the $\mathrm{pH}$ of 11 , the removal efficiency of copper and lead decrease. It is true since the metal hydroxides formed as the coagulants can be dissociated into the soluble metal cations at higher than pH 9 (Kim et al. 2020). This fact confirms that the solubility of coagulants strongly depends on the acidity of the solution (Chen et al. 2018). On the other hand, at $\mathrm{pH}$ above 9, soluble compounds, such as $\left[\mathrm{Al}(\mathrm{OH})_{4}\right]^{-}$, were generated and may lack the process (Cañizares et al. 2009; Prasetyaningrum et al. 2019). Other researchers also reported that $\mathrm{pH}$ has an influence on the EC process performance, such as in the copper removal (Kim et al. 2014; Yilmaz et al. 2008) and removal of $\mathrm{Cu}, \mathrm{Ni}$, and $\mathrm{Mn}$ (Al-Aji et al. 2012). According to Merma et al. $(2020), \mathrm{Al}(\mathrm{OH})_{3}$ is precipitated at the $\mathrm{pH}$ range of 5 and 9.5 , while at $\mathrm{pH}$ higher than $9.5,\left[\mathrm{Al}(\mathrm{OH})_{4}\right]^{-}$ is the major species. Therefore, it is suggested that the decrease in the efficiency of $\mathrm{Cu}$ and $\mathrm{Pb}$ ions removal at $\mathrm{pH}$ 11 is due to the dissociation of metal hydroxides and the generation of $\left[\mathrm{Al}(\mathrm{OH})_{4}\right]^{-}$species which is a soluble species.

As explained before, the value wastewater $\mathrm{pH}$ affects the aluminum hydroxide or polyaluminum hydroxymetallic compounds formation because those compounds are produced by the reaction of $\mathrm{OH}^{-}$at the cathode and $\mathrm{Al}^{3+}$ at the anode. The flocs of aluminum hydroxide attended as a coagulant agent and have high adsorption for $\mathrm{Cu}$ and $\mathrm{Pb}$ ions so that precipitation occurs. The adsorption phenomenon is caused by the link structure that forms between colloidal particles of aluminum particles. However, it should be noted that the efficiency of $\mathrm{Cu}$ removal at a $\mathrm{pH}$ of 3 is low. It confirms that at acidic conditions, the copper removal is low. This is because of the low formation of coagulant species at the acidic condition. Within this acidic condition, the concentrations of $\mathrm{OH}^{-}$were not adequate to form the metal hydroxide species (Kim et al. 2020). As a result, it is not easy to produce enough $\mathrm{OH}^{-}$ions for metal hydroxide production in an acidic condition. In line with this finding, Merma et al. (2020) explained that the stable component of aluminum at a $\mathrm{pH}$ lower than 5 is $\mathrm{Al}^{3+}$. It means that the $\mathrm{Al}(\mathrm{OH})_{3}$ as the coagulant at EC treatment is difficult to be generated. Therefore, the efficiency of $\mathrm{Cu}$ removal at a $\mathrm{pH}$ of 3 is low because of the low formation of metal hydroxide since the metal hydroxide is the coagulant for the ion removal.

Regarding the lead removal, as can be observed, the removal efficiency of $\mathrm{Pb}$ is high at all varied $\mathrm{pH}$ values and seems to be independent of the $\mathrm{pH}$ value. This result is obtained because the lead concentration in the solution is low enough, which is $10.92 \mathrm{mg} . \mathrm{L}^{-1}$. On the other hand, lead ions can be precipitated at a low $\mathrm{pH}$ range of 1 to 5 as $\mathrm{Pb}(\mathrm{OH})_{2}, \mathrm{PbCO}_{3}$, and $\mathrm{Pb}_{3}\left(\mathrm{CO}_{3}\right)_{2}(\mathrm{OH})_{2}$ (Bouguerra et al. 2015). It is suggested that in an acidic condition, the lead ion removal is due to the precipitation process, while in the alkaline condition, the lead ion removal is due to the EC process. Therefore, the lead removal at all varied $\mathrm{pH}$ is high enough.

\subsection{The kinetic study of the EC process}

\subsubsection{Kinetics Model}

The $\mathrm{Cu}$ and $\mathrm{Pb}$ ions removal rates have been studied using the first-order and pseudo-first-order models kinetics equations at varied current densities and $\mathrm{pHs}$. The comparison of the kinetic rate parameters of the firstorder and pseudo-first-order models for the removal rates of $\mathrm{Cu}$ and $\mathrm{Pb}$ ions at different current density is depicted in Table 1, and the comparison of data and model data using the kinetic models (Eq. (14) and (17)) is depicted in Fig. 6.

The obtained values indicate that the first-order and pseudo-second-order models are suitable to describe the kinetic model of $\mathrm{Cu}$ and $\mathrm{Pb}$ ions removal in the EC process. The values show that the models were both suitable in describing the kinetics model of the $\mathrm{Cu}$ and $\mathrm{Pb}$ ions removal in the EC process with $\mathrm{R}^{2}$ values above 0.9 . However, the first-order is used when the equilibrium concentration is low. In this experiment, the $C_{e}$ values of $\mathrm{Cu}$ ions removal at $80 \mathrm{~A} / \mathrm{m}^{2}$ and the $C_{e}$ values of $\mathrm{Pb}$ ions at 70 and $80 \mathrm{~A} / \mathrm{m}^{2}$ were zero. When the $C_{e}$ value is zero, the pseudo-first-order becomes the first-order model (Prasetyaningrum et al. 2020). Besides, Chen et al. (2018) has reported that in some cases, when the pseudo-firstorder model is forcibly used, the value of $C_{e}$ might be negative. Therefore, the first-order model is more appropriate to predict the copper and lead ions removal process. According to Al-Shannag et al. (2015), the value of kinetic rate constants varies at different current densities. Meanwhile, this research shows the different parameters in the $\mathrm{pH}$. 
Citation: Prasetyaningrum, A., Ariyanti, D., Widayat, W., Jos, B. (2021) Copper and Lead Ions Removal by Electrocoagulation: Process Performance and Implications for Energy Consumption. Int. Journal of Renewable Energy Development, 10(3), 415-424, doi: 10.14710/ijred.2021.31665

$\mathrm{P}$ a g e $\mid 420$

Table 1

Kinetic parameters of copper and lead ions removal at varied current densities

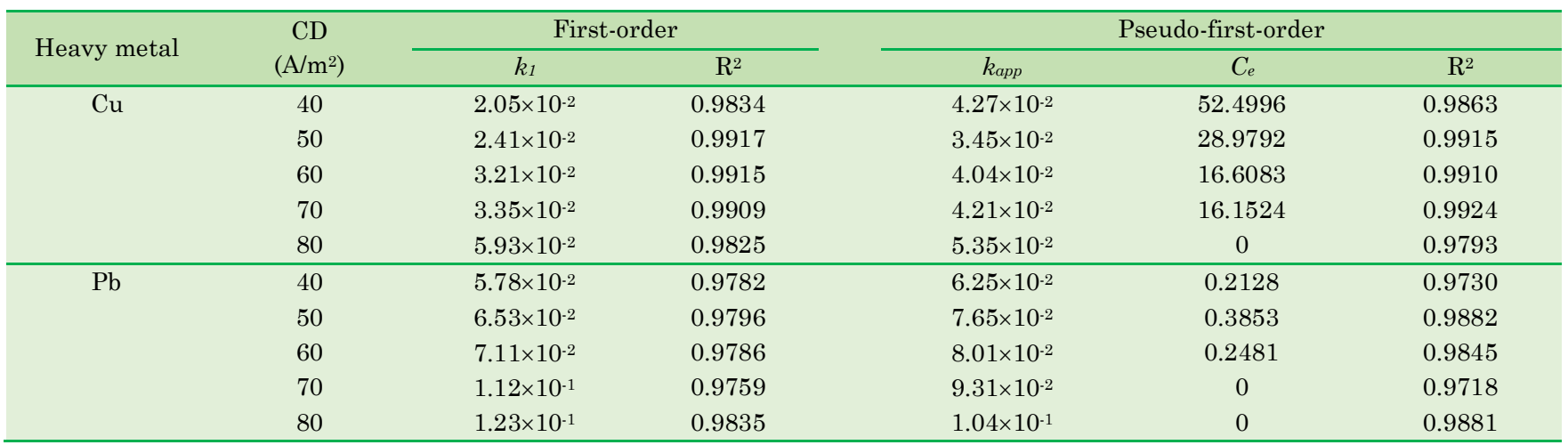
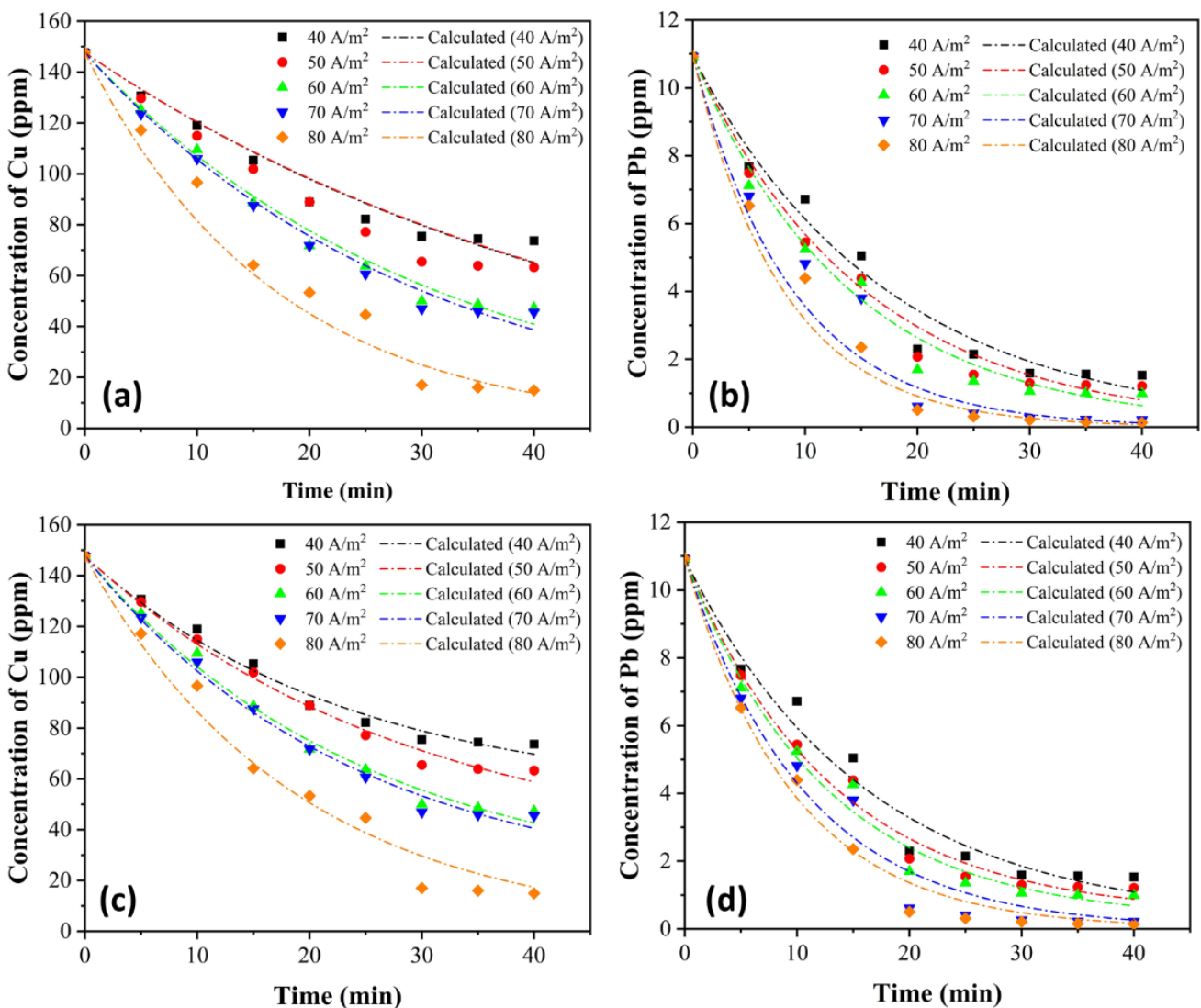

Fig. 6 The comparison of experimental and modelled data at varied current density for first-order of $\mathrm{Cu}(\mathrm{a})$ and $\mathrm{Pb}$ (b) and pseudo-firstorder of $\mathrm{Cu}(\mathrm{c})$ and $\mathrm{Pb}(\mathrm{d})$

Table 2

Kinetic parameters of copper and lead ions removal at different $\mathrm{pH}$

\begin{tabular}{|c|c|c|c|c|c|c|}
\hline \multirow{2}{*}{ Heavy metal } & \multirow{2}{*}{$\mathrm{pH}$} & \multicolumn{2}{|c|}{ First-order } & \multicolumn{3}{|c|}{ Pseudo-first-order } \\
\hline & & $k_{1}$ & $\mathrm{R}^{2}$ & $k_{a p p}$ & $C_{e}$ & $\mathrm{R}^{2}$ \\
\hline \multirow[t]{5}{*}{$\mathrm{Cu}$} & 3 & $2.53 \times 10^{-3}$ & 0.9710 & $4.51 \times 10^{-2}$ & 132.8654 & 0.9823 \\
\hline & 5 & $1.49 \times 10^{-2}$ & 0.9872 & $3.41 \times 10^{-2}$ & 63.4878 & 0.9859 \\
\hline & 7 & $2.13 \times 10^{-2}$ & 0.9847 & $4.36 \times 10^{-2}$ & 50.6771 & 0.9902 \\
\hline & 9 & $3.58 \times 10^{-2}$ & 0.9870 & $5.73 \times 10^{-2}$ & 28.0163 & 0.9869 \\
\hline & 11 & $1.74 \times 10^{-2}$ & 0.9874 & $3.89 \times 10^{-2}$ & 59.4721 & 0.9886 \\
\hline \multirow[t]{5}{*}{$\mathrm{Pb}$} & 3 & $3.58 \times 10^{-2}$ & 0.9819 & $4.31 \times 10^{-2}$ & 1.0415 & 0.9534 \\
\hline & 5 & $5.58 \times 10^{-2}$ & 0.9873 & $7.25 \times 10^{-2}$ & 0.8112 & 0.9974 \\
\hline & 7 & $6.68 \times 10^{-2}$ & 0.9896 & $8.37 \times 10^{-2}$ & 0.5880 & 0.9920 \\
\hline & 9 & $9.82 \times 10^{-2}$ & 0.9956 & $9.86 \times 10^{-2}$ & 0 & 0.9968 \\
\hline & 11 & $4.96 \times 10^{-2}$ & 0.9905 & $4.86 \times 10^{-2}$ & 0 & 0.9886 \\
\hline
\end{tabular}



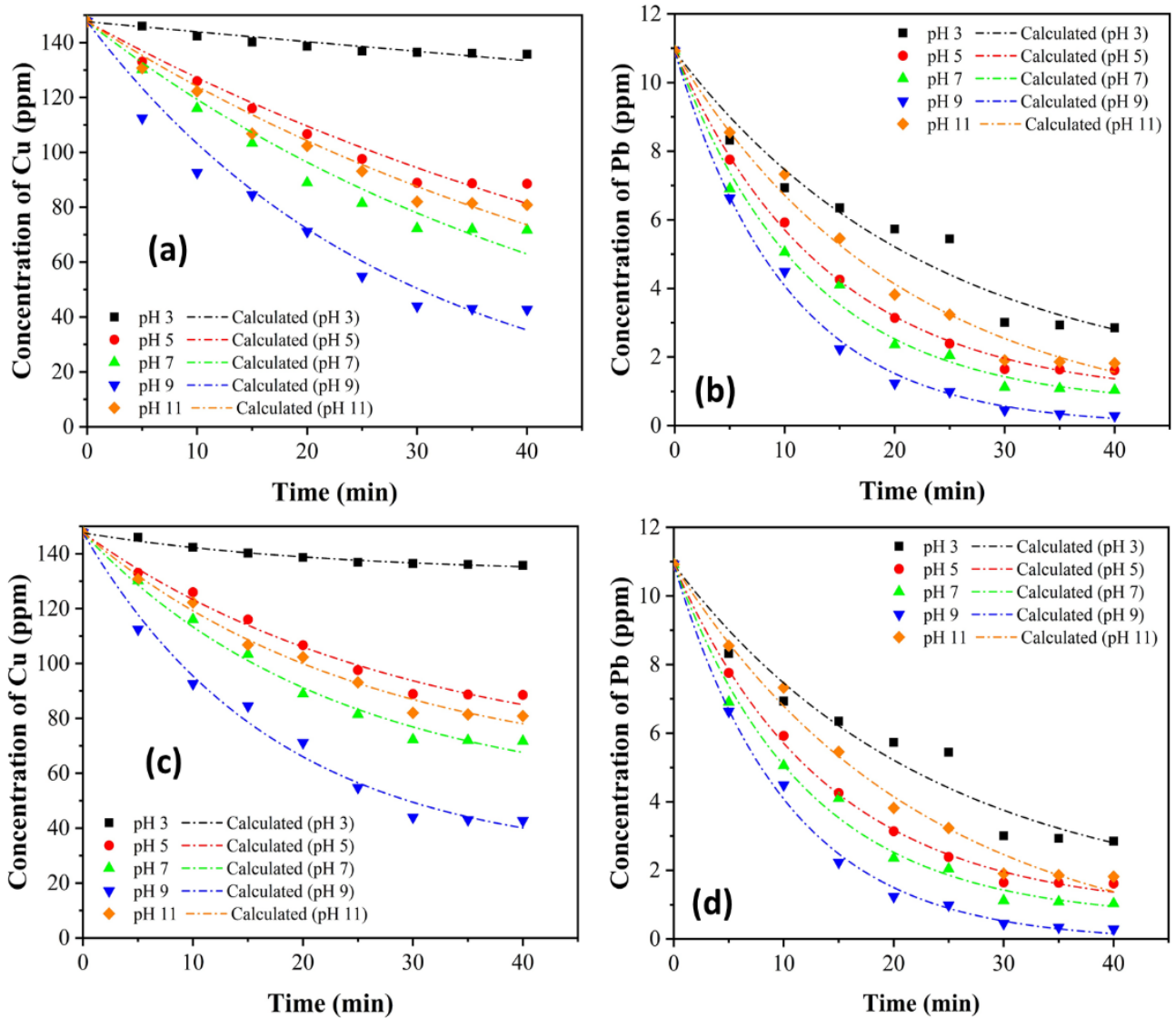

Fig. 7 The comparison of experimental and modeled data at varied $\mathrm{pH}$ for first-order of $\mathrm{Cu}(\mathrm{a})$ and $\mathrm{Pb}(\mathrm{b})$ and pseudo-first-order of $\mathrm{Cu}$ (c) and $\mathrm{Pb}(\mathrm{d})$

Table 2 displays the kinetic rate parameters of the firstorder and pseudo-first-order models at varied $\mathrm{pH}$ values, while the comparison of the experimental and model data using Eq. (14) and (17) is depicted in Fig. 7. This shows that the copper removal using the EC process fits properly with $\mathrm{R}^{2}$ values above 0.95 . On the other hand, the $C_{e}$ values of lead ions removal at $\mathrm{pH}$ of 9 and 11 were zero. In this case, we conclude that the first-order model is more appropriate to describe the $\mathrm{Pb}$ ions removal process.

Some researchers modeled the kinetic rates of the EC process of metal ions removal in the adsorption step. Yllmaz et al. (2008) found a pseudo-second-order homogeneous reaction model for boron removal by EC using aluminum anode. Vasudevan et al. (2009) and Xi et al. (2015) found that the first and second-order models appropriately fitted with the simultaneous removal of mercury, lead, nickel, and cadmium. It is related to the varying coagulant ions properties, the pollutants nature, and the operating parameters.

\subsubsection{Effect of concentration of $\mathrm{Cu}^{2+}$ and $\mathrm{Pb}^{2+}$ on the kinetic of the EC process}

The correlation of kinetic rate constant and the initial concentration of $\mathrm{Cu}^{2+}$ and $\mathrm{Pb}^{2+}$ can be written as follows (Eq. (18) - (20))

$$
k=f\left(C_{C u}, C_{P b}\right)
$$

$$
\begin{gathered}
k=\alpha C_{C u}^{a} C_{P b}^{b} \\
\ln k=\ln \alpha+a \ln C_{C u}+b \ln C_{P b}
\end{gathered}
$$

The value of $k$ is the kinetic rate constant of the electrocoagulation process from the first-order model, while $\alpha, a$, and $b$ are the constants. The determination of those constants can be derived using the multiple regression analysis (MRA) as reported elsewhere (Prasetyaningrum et al. 2020).

The multiple regression analysis is a method that is able to determine the constant values $\alpha, a$, and $b$. These constants are determined simultaneously. Using the MRA methods, the obtained values of $\alpha, a$ and $b$ are $4.295 \times 10^{-7}$, -0.1200 , and -0.6616 , respectively, with $R^{2}$ is 0.9477 . Therefore, the overall equation for modeling the relation correlating the kinetic rate constant and the concentration of $\mathrm{Cu}^{2+}$ and $\mathrm{Pb}^{2+}$ can be written as follows (Eq. (21)).

$$
k=4.295 \times 10^{-7} C_{C u}^{-0.1200} C_{P b}^{-0.6616}
$$

As can be observed from Eq. (21), the exponent value of $C_{C u}$ and $C_{P b}$ is negative. It indicates that the concentration of $\mathrm{Cu}$ dan $\mathrm{Pb}$ has a negative effect on the value of the kinetic rate constant. The higher the $\mathrm{Cu}$ dan $\mathrm{Pb}$ concentrations, the lower the kinetic rate constant value. This finding is in line with the result of the previously reported study. The initial concentration of the heavy metals is negatively proportional to the kinetic rate 
Citation: Prasetyaningrum, A., Ariyanti, D., Widayat, W., Jos, B. (2021) Copper and Lead Ions Removal by Electrocoagulation: Process Performance and Implications for Energy Consumption. Int. Journal of Renewable Energy Development, 10(3), 415-424, doi: 10.14710/ijred.2021.31665

$\mathrm{P}$ a g e 1422

constant (Prasetyaningrum et al. 2020). In addition, Eq. (21) shows that the exponent value of $C_{C u}$ is higher than the exponent value of $\mathrm{CPb}$. It indicates that the value of the kinetic rate constant is more influenced by the concentration of $\mathrm{Cu}$ rather than be influenced by the concentration of $\mathrm{Pb}$. The different concentration of $\mathrm{Cu}^{2+}$ and $\mathrm{Pb}^{2+}$ are $35,75,100,147.63 \mathrm{ppm}$ for $\mathrm{Cu}^{2+}$ and $2.5,5$, 7.5, $10.92 \mathrm{ppm}$ for $\mathrm{Pb}^{2+}$ for removal efficiency $88.2 \%$, $90.12 \%, 92.10 \%, 89.88 \%$ for $\mathrm{Cu}$ and $90.43 \%, 96.12 \%$, 99.34\% and $98.76 \%$ for $\mathrm{Pb}$, respectively. Some research about the effect of initial concentration has been studied. Al-Aji et al. (2012) have reported that a high value in the initial concentration of heavy metals was reduced in relatively less time than the low concentration. The EC treatment is more effective at the beginning of the process when the concentration is relatively low. Al-Aji et al. (2012) have reported that using the EC process for $40 \mathrm{~min}$ at the current density of $8 \mathrm{~mA} / \mathrm{cm}^{2}$, the $\mathrm{Cu}$ ions concentrations in the wastewater were reduced from initial $\mathrm{Cu}$ concentration of 50, 100, 150, and $250 \mathrm{mg} / \mathrm{L}$ were reduced to $1.9,2.55,4$, and $7.9 \mathrm{mg} / \mathrm{L}$ with a removal efficiency of $96.2 \%, 97.45 \%, 97.3 \%$, and $96.84 \%$, respectively. Dermentzis et al. (2016) have reported relatively the same results. For a high concentration, a longer time for the removal process is required, but a high initial concentration was more effective. Kim et al. (2014) had reported that the initial concentration of $\mathrm{Cu}$ and $\mathrm{Pb}$ ions had no effect on removal efficiency when the concentrations were 10 and $50 \mathrm{mg} / \mathrm{L}$. Nevertheless, the value of the initial concentration had significantly affected the removal efficiency when it was $100 \mathrm{mg} / \mathrm{L}$. Therefore, the higher value of the initial concentration results in a higher removal efficiency than the lower concentration.

\subsection{Energy and Electrodes Consumptions}

The dissolved electrode amount and electrical energy requirement per volume of wastewater were examined in this study. Furthermore, the correlation of removal efficiencies at different CD and EC times also studied. As shown in Table 3, the energy consumption as well as the number of dissolved electrodes depend on the electrocoagulation time and current density, as it increases along with the addition of electrocoagulation time and current density.

The application of current density from 40 to $80 \mathrm{~A} / \mathrm{m}^{2}$ will increase copper removal efficiency from 50.08 to $89.88 \%$. However, under these conditions, energy requirements increase from 4.44 to $21.60 \mathrm{~kW} \mathrm{~h} / \mathrm{m}^{3}$. Furthermore, the removal of lead ions increases from 86.01 to $98.76 \%$, and the energy consumption increases from 4.44 to 21.60 at the $\mathrm{CD}$ of 40 to $80 \mathrm{~A} / \mathrm{m}^{2}$. At $40 \mathrm{~min}$ of the EC process, the number of dissolved electrodes increases from $0.1398 \mathrm{~kg} / \mathrm{m}^{3}$ to $0.2201 \mathrm{~kg} / \mathrm{m}^{3}$ at the current density of 40 to $80 \mathrm{~A} / \mathrm{m}^{2}$. The results of this study indicate that the current density should not be carried out below $80 \mathrm{~mA} / \mathrm{cm}^{2}$, and the time of the EC process is ranged between 20 to $40 \mathrm{~min}$. In these conditions, the specific energy consumptions are ranged to the level of 10.80$21.60 \mathrm{kWh} / \mathrm{m}^{3}$, and the specific amounts of dissolved electrodes are ranged to the level of $0.0988-0.2201 \mathrm{~kg} / \mathrm{m}^{3}$. The results of this study show a relationship between an increase in specific energy requirements and the dissolution of certain electrodes.
Table 3

Removal efficiencies, amount electrodes dissolved, and electrical energy requirements at varied current densities at $\mathrm{pH} 9$

\begin{tabular}{cccccc}
\hline \multirow{2}{*}{$\begin{array}{c}\mathrm{t} \\
(\mathrm{min})\end{array}$} & $\begin{array}{c}\mathrm{CD} \\
\left(\mathrm{A} / \mathrm{m}^{2}\right)\end{array}$ & $\begin{array}{c}\mathrm{E} \\
\left(\mathrm{kWhr} / \mathrm{m}^{3)}\right.\end{array}$ & $\begin{array}{c}\mathrm{mAl} \\
\left(\mathrm{kg} / \mathrm{m}^{3}\right)\end{array}$ & \multicolumn{2}{c}{$\begin{array}{c}\text { Removal } \\
\text { efficiency (\%) }\end{array}$} \\
\hline \multirow{2}{2}{20} & 40 & 2.00 & 0.0654 & 39.76 & 78.98 \\
& 50 & 3.63 & 0.0768 & 39.76 & 80.98 \\
& 60 & 5.82 & 0.0844 & 51.40 & 84.48 \\
& 70 & 8.33 & 0.0951 & 51.40 & 94.41 \\
& 80 & 10.80 & 0.0988 & 63.86 & 95.37 \\
\hline 40 & 40 & 4.44 & 0.1398 & 50.08 & 86.01 \\
& 50 & 6.80 & 0.1492 & 57.14 & 88.92 \\
& 60 & 12.71 & 0.1686 & 67.95 & 90.91 \\
& 70 & 16.33 & 0.1902 & 69.13 & 98.01 \\
& 80 & 21.60 & 0.2201 & 89.88 & 98.76 \\
\hline
\end{tabular}

The electrical energy requirement and the amount of the dissolved electrode in the EC process affect the economic factors. Some studies have reported that the current density is a notable factor in EC performance. Yllmaz et al. (2008) reported that the energy consumption of boron removal increased with increasing current density. Chen et al. (2018) reported an efficient removal of $\mathrm{Zn}^{2+}$ with controllable current density. Meanwhile, according to Al-Shannag et al. (2013), the current density and electrocoagulation time can be used to control the number of specific power consumption and the specific dissolution of electrodes. By applying current density 40 $\mathrm{A} / \mathrm{m}^{2}$ and electrocoagulation time 45 minutes, the energy consumption was recorded $6.25 \mathrm{kWh} / \mathrm{m}^{3}$. Eventhough detailed cost analysis is needed to validate the feasibility electrocoagulation process. They reported that for $95 \%$ removal of $\mathrm{Zn}^{2+}$, the energy consumption was $0.25 \mathrm{kWh} / \mathrm{m}^{3}$ at a current density of $83 \mathrm{~A} / \mathrm{m}^{2}$. Compared to these reports, it can be seen that the energy consumption obtained in this study is different. The difference in energy consumption is due to the different operating parameters. Akbal and Camc1 (2011) explained that energy consumption depends on several operating parameters, especially the electrode materials and wastewater conductivity.

It can be seen from Table 3, the higher the value of current density, the higher the value of energy consumption. The number of electrodes dissolved per unit volume also shows the same results. This data can be used to support the process design activity related to the EC for heavy metal removal.

Finally, the amount of energy and electricity requirements during the EC greatly influences the operating cost. Some researchers have developed the empirical equation to calculate the operating cost. Ozyonar and Karagozoglu (2011) calculated the operating cost with electrodes and electrical cost. They assumed that both the costs of electrode and energy consumption were taken as the main cost items expressed as follows:

$$
O C=a C_{\text {Energy }}+b C_{\text {Electrode }}
$$

where $O C$ is the operating cost $(\$), a$ is the unit price of electrical energy price $(\$ / \mathrm{kWh}), C_{\text {Energy }}$ is the energy consumption (kWh), which can be calculated from Eq. (11), $b$ is the unit price electrode material price $(\$ / \mathrm{kg})$, and $C_{\text {Electrode }}$ is the electrode consumption which can be 
calculated from Eq. (12). More complex, Kobya et al. (2010) included the chemicals consumed in the process as the main cost item to the equation. Similar to the assessment result, the cost of EC process depends on the energy consumption used during the process.

\section{Conclusion}

This research studied the removal process of $\mathrm{Cu}$ and $\mathrm{Pb}$ ions from synthesized electroplating wastewater using a batch EC process. Current density is a significant key parameter for reducing wastewater using the EC process. The efficiency of $\mathrm{Cu}$ and $\mathrm{Pb}$ ions removal increased as the current density increased. The removal of heavy metal ions significantly improves with the residence time of the EC process and current density. The applied current density should not be higher than $80 \mathrm{~A} / \mathrm{m}^{2}$, and the EC time should be ranged at 20 to $40 \mathrm{~min}$ to minimize the energy requirement, even though the removal efficiency was maintained in a high number. In addition, the $\mathrm{pH}$ value of the wastewater should be maintained at $\mathrm{pH}$ 7-9 to obtain optimal removal of $\mathrm{Cu}$ and $\mathrm{Pb}$ ions. At this condition, the specific energy consumption is ranged from $10.80-21.60 \mathrm{kWh} / \mathrm{m}^{3}$ and the dissolved electrodes of $0.0988-0.2201 \mathrm{~kg} / \mathrm{m}^{3}$. The correlation between the kinetic rate constant and the concentration of $\mathrm{Cu}^{2+}$ and $\mathrm{Pb}^{2+}$ is expressed as $k=4.295 \times 10^{-7} C_{C u}^{-0.1200} C_{P b}^{-0.6616}$. In conclusion, the EC process can be used as one of the alternative methods for copper and lead ions removal from electroplating wastewater. Further research and development in the pilot scale size in continuous mode along with sludge management study are necessary to support the development of EC process to be implemented in the industrial electroplating wastewater treatment.

\section{Acknowledgments}

We would like to express our gratitude to Diponegoro University, Indonesia for funding research and facilities.

\section{References}

Abrahamsen, E.B., Asche, F. and Milazzo, M.F. (2013). An evaluation of the effects on safety of using safety standards in major hazard industries. Safety Science, 59, 173-178; doi: 10.1016/j.ssci.2013.05.011

Adhoum, N., Monser, L., Bellakhal, N. and Belgaied, J.E. (2004). Treatment of electroplating wastewater containing $\mathrm{Cu}^{2+}$, $\mathrm{Zn}^{2+}$ and $\mathrm{Cr}^{6+}$ by electrocoagulation. Journal of Hazardous Materials, 112(3), 207-213; doi: 10.1016/j.jhazmat.2004.04.018

Agridiotis, V., Forster, C.F. and Carliell-Marquet, C. (2007). Addition of $\mathrm{Al}$ and $\mathrm{Fe}$ salts during treatment of paper mill effluents to improve activated sludge settlement characteristics. Bioresource Technology, 98, 2926-2934; doi: 10.1016/j.biortech.2006.10.004

Akbal, F. and Camc1, S. (2011). Copper, chromium and nickel removal from metal plating wastewater by electrocoagulation. Desalination, 269, 214-222; doi: 10.1016/j.desal.2010.11.001

Al-Aji, B., Yavuz, Y. and Koparal, A. S. (2012). Electrocoagulation of heavy metals containing model wastewater using monopolar iron electrodes. Separation and Purification Technology, 86, 248-254; doi: 10.1016/j.seppur.2011.11.011

Al-Shannag, M., Al-Qodah, Z., Bani-Melhem, K., Qtaishat, M.R. and Alkasrawi, M. (2015). Heavy metal ions removal from metal plating wastewater using electrocoagulation: kinetic study and process performance. Chemical Engineering Journal, 260, 749-756; doi: 10.1016/j.cej.2014.09.035

Al-Shannag, M., Bani-Melhem, K., Al-Anber, Z. and Al-Qodah, Z. (2013). Enhancement of COD-nutrients removals and filterability of secondary clarifier municipal wastewater influent using electrocoagulation technique. Separation Science and Technology, 48, 673-68; doi: 10.1080/01496395.2012.707729

Basha, C.A., Bhadrinarayana, N.S., Anantharaman, N. And Begum, K.M. (2008). Heavy metal removal from copper smelting effluent using electrochemical cylindrical flow reactor. Journal of Hazardous Materials, 152, 71-78; doi: 10.1016/j.jhazmat.2007.06.069

Bener, S., Bulca, Ö., Palas, B., Tekin, G., Atalay, S. and Ersöz, G. (2019). Electrocoagulation process for the treatment of real textile wastewater: Effect of operative conditions on the organic carbon removal and kinetic study. Process Safety and Environmental Protection, 129, 47-54; doi: 10.1016/j.psep.2019.06.010

Beyazit, N. (2014). Copper(II), Chromium(VI) and Nickel (II) Removal from metal plating effluent by electrocoagulation. International Journal of Electrochemical Science, 9, 43154330.

Bouguerra, W., Barhoumi, A., Ibrahim, N., Brahmi, K., Aloui, L. and Hamrouni, B. (2015). Optimization of the electrocoagulation process for the removal of lead from water using aluminium as electrode material. Desalination and Water Treatment, 56(10), 2672-2681; doi: 10.1080/19443994.2015.1015308

Cañizares, P., Martínez, F., Jiménez, C., Sáez, C. and Manuel, A.R. (2009). Technical and economic comparison of conventional and electrochemical coagulation processes. $J$. Chem Technology and Biotechnology, 84, 702-710; doi: 10.1002/jctb. 2102

Chen, G. (2004). Electrochemical technologies in wastewater treatment. Separation and Purification Technology, 38, 1141; doi: 10.1016/j.seppur.2003.10.006

Chen, X., Ren, P., Li, T., Jason, P. and Liu, X. (2018). Zinc removal from model wastewater by electrocoagulation: Processing, kinetics, and mechanism. Chemical Engineering Journal, 349, 358-367; doi: 10.1016/j.cej.2018.05.099

Cotillas, S., Canizares, P., Martin De Vidales, M.J., Saez, C., Rodrigo, M. and Llanos, J. (2014). Electrocoagulation-UVirradiation process for urban wastewater reuse. Chemical Engineering Transactions, 41, 133-138; doi: 10.3303/CET1441023

Das, D. and Nandi, B.K. (2019). Removal of Fe (II) ions from drinking water using Electrocoagulation (EC) process: Parametric optimization and kinetic study. Journal of Environmental Chemical Engineering, 7, 103116; doi: 10.1016/j.jece.2019.103116

Dermentzis, K., Stergiopoulos, D., Giannakoudakis, P. and Moumtzakis, A. (2016). Removal of copper and COD from electroplating effluents by photovoltaic electrocoagulation / electrooxidation process. Water Utility Journal, 14, 55-62.

Fabiano, B., Currò, F., A.P. Reverberi, A.P. and Palazzi, E. (2014). Coal dust emissions: from environmental control to risk minimization by underground transport. An applicative case-study. Process Safety and Environmental Protection, 92(4), 150-159; doi: 10.1016/j.psep.2013.01.002.

Flores, N., Brillas, E., Centellas, F., Rodríguez, R.M., Cabot, P.L., Garrido, J.A. and Sirés, I. (2018). Treatment of olive oil mill wastewater by single electrocoagulation with different electrodes and sequential electrocoagulation/electrochemical Fenton-based processes. Journal of Hazardous Materials, 347, 58-66; doi: 10.1016/j.jhazmat.2017.12.059 
Hossain, M.M., Mahmud, M.I., Parvez, M.S. and Cho, H.M. (2013). Impact of current density, operating time and $\mathrm{pH}$ of textile wastewater treatment by electrocoagulation process. Environmental Engineering Research, 18(3), 157-161; doi: 10.4491/eer.2013.18.3.157

Hunsom, M., Pruksathorn, K., Damronglerd, S., Vergnes, H. And Duverneuil, P. (2005). Electrochemical treatment of heavy metals $\left(\mathrm{Cu}^{2+}, \mathrm{Cr}^{6+}, \mathrm{Ni}^{2+}\right)$ from industrial effluent and modeling of copper reduction. Water Research, 39(4), 610616; doi: 10.1016/j.watres.2004.10.011

Kim, D.G., Palacios, R.J.S. and Ko, S.O. (2014). Characterization of sludge generated by electrocoagulation for the removal of heavy metals. Desalination and Water Treatment, 52, 909919; doi: 10.1080/19443994.2013.826776

Kim, T., Kim, T.-K. and Zoh, K.-D. (2020). Removal mechanism of heavy metal $(\mathrm{Cu}, \mathrm{Ni}, \mathrm{Zn}$, and $\mathrm{Cr})$ in the presence of cyanide during electrocoagulation using $\mathrm{Fe}$ and $\mathrm{Al}$ electrodes. Journal of Water Process Engineering, 33, 101109; doi: 10.1016/j.jwpe.2019.101109

Kobya, M. and Delipinar, S. (2008). Treatment of the baker's yeast wastewater by electrocoagulation. Journal of Hazardous Materials, 154, 1133-1140; doi: 10.1016/j.jhazmat.2007.11.019

Kobya, M., Demirbas, E., Parlaka, N.U. and Yigit, S. (2010). Treatment of cadmium and nickel electroplating rinse water by electrocoagulation. Environmental Technology, 31(13), 1471-1481; doi: 10.1080/0959333100371369

Kobya, M., Hiz, H., Senturk, E., Aydiner, C. and Demirbas, E. (2006). Treatment of potato chips manufacturing wastewater by electrocoagulation. Desalination, 190, 201211; doi: 10.1016/j.desal.2005.10.006

Martınez-Huitle, C.A. and Brillas, E. (2009). Decontamination of wastewaters containing synthetic organic dyes by electrochemical methods: a general review. Applied Catalysis B: Environmental, 87, 105-145; doi: 10.1016/j.apcatb.2008.09.017

Merma, A.G., Santos, B.F., Rego, A.S.C., Hacha, R.R. and Torem, M.L. (2020). Treatment of oily wastewater from mining industry using electrocoagulation: Fundamentals and process optimization. Journal of Materials Research and Technology, 9(6), 15164-15176; doi: 10.1016/j.jmrt.2020.10.107

Moradi, M., Vasseghian, Y., Arabzade, H. and Khaneghah, A.M. (2021). Various wastewaters treatment by sonoelectrocoagulation process: A comprehensive review of operational parameters and future outlook. Chemosphere, 263, 128314; doi: 10.1016/j.chemosphere.2020.128314

Nasrullah, M., Lakhveer, S. and Wahid, Z.A. (2012). Treatment of sewage by electrocoagulation and the effect of high current density. Energy and Environmental Engineering Journal, 1(1), 27-31; doi: 10.14233/ajchem.2014.16134

Ozyonar, F. and Karagozoglu, B. (2011). Operating Cost Analysis and Treatment of Domestic Wastewater by Electrocoagulation Using Aluminum Electrodes. Polish Journal of Environmental Studies, 20(1), 173-179.

Pandey, N. and Thakur, C. (2020). Study on treatment of paper mill wastewater by electrocoagulation and its sludge analysis. Chemical Data Collections, 27, 100390; doi: 10.1016/j.cdc.2020.100390

Prasetyaningrum, A., Jos, B., Dharmawan, Y. and Praptyana I.R. (2019). The Effect of $\mathrm{pH}$ and Current Density on
Electrocoagulation Process for Degradation of Chromium (VI) in Plating Industrial Wastewater. Journal of Physics: Conference Series, 1295, 012064; doi: 10.1088/1742$6596 / 1295 / 1 / 012064$

Prasetyaningrum, A., Jos, B., Dharmawan, Y., Prabowo, B.T., Fathurrazan, M. and Fyrouzabadi, F. (2018). The influence of electrode type on electrocoagulation process for removal of chromium (VI) metal in plating industrial wastewater. Journal of Physics: Conference Series, 1025, 012126; doi: 10.1088/1742-6596/1025/1/012126

Prasetyaningrum, A., Riyanto, T., Djaeni, M. and Widayat, W. (2020). Photochemical Oxidation Process of Copper from Electroplating Wastewater: Process Performance and Kinetic Study. Processes, 8(10), 1276; doi: 10.3390/pr8101276

Pulkka, S., Martikainen, M., Bhatnagar, A. and Sillanpää, M. (2014). Electrochemical methods for the removal of anionic contaminants from water-A review. Separation and Purification Technology, 132, 252-271; doi: 10.1016/j.seppur.2014.05.021

Reverberi, A.P., Maga, L., Cerrato, C. and Fabiano, B. (2014). Membrane processes for water recovery and decontamination. Current Opinion in Chemical Engineering, 6, 75-82; doi: 10.1016/j.coche.2014.10.004

Samsami, S., Mohamadi, M., Sarrafzadeh, M.-H., Rene, E.R. and Firoozbhahr, M. (2020). Recent advances in the treatment of dye-containing wastewater from textile industries: Overview and perspectives. Process Safety and Environmental Protection, 143, 138-163; doi: 10.1016/j.psep.2020.05.034

Shahedi, A., Darban, A.K., Taghipour, F. and Jamshidi-Zanjani, A. (2020). A review on industrial wastewater treatment via electrocoagulation processes. Current Opinion in Electrochemistry, $22, \quad 154-169 ; \quad$ doi: 10.1016/j.coelec.2020.05.009

Tchobanoglous, G., Burton, F.L. and Stensel, H.D. (2003). Wastewater Engineering: Treatment and Reuse, Fourth ed., McGraw Hill, Boston.

Vasudevan, S., Lakshmi, J. and Sozhan, G. (2009). Studies on the removal of iron from drinking water by electrocoagulation A clean process. CLEAN, 37, 45-51; doi: 10.1002/clen.200800175

Xi, Y., Luo, Y. and Luo, X. (2015). Removal of Cadmium (II) from Wastewater Using Novel Cadmium Ion-Imprinted Polymers. Journal of Chemical \& Engineering Data, 60, 3253-3261; doi: 10.1021/acs.jced.5b00494

Yılmaz, A.E., Boncukcuoğlu, R., Kocaker, M.M. and Kocadağistan, E. (2008). An empirical model for kinetics of boron removal from boron containing wastewaters by the electrocoagulation method in a batch reactor. Desalination, 230, 288-297; doi: 10.1016/j.desal.2007.11.031

Zhu, B., Clifford, D.A. and Chellam, S. (2005). Comparison of electrocoagulation and chemical coagulation pretreatment for enhanced virus removal using microfiltration membranes. Water Research, 39, 3098-3108; doi: 10.1016/j.watres.2005.05.020

Zini, L.P., Longhi, M., Jonko, E. and Giovanela, M. (2020). Treatment of automotive industry wastewater by electrocoagulation using commercial aluminum electrodes. Process Safety and Environmental Protection, 142, 272284; doi: 10.1016/j.psep.2020.06.029 